\title{
PENGEMBANGAN MODUL ELEKTRONIK FISIKA BERBASIS PENDEKATAN SAINTIFIK MATERI GETARAN HARMONIS MENGGUNAKAN KVISOFT FLIPBOOK MAKER
}

Dewi Ayu Puspita Sari ${ }^{1}$, M. Hidayat ${ }^{2}$, dan Wawan Kurniawan ${ }^{3}$

${ }^{1}$ Mahasiswa S1 Program Studi Pendidikan Fisika FKIP Universitas Jambi

${ }^{2,3}$ Dosen Program Studi Pendidikan Fisika FKIP Universitas Jambi

Email: dewiayupuspitasari17@gmail.com

\begin{tabular}{|c|c|}
\hline $\begin{array}{l}\text { Info Artikel } \\
\text { Diterima: } \\
\text { Disetujui: } \\
\text { Dipublikasikan: }\end{array}$ & 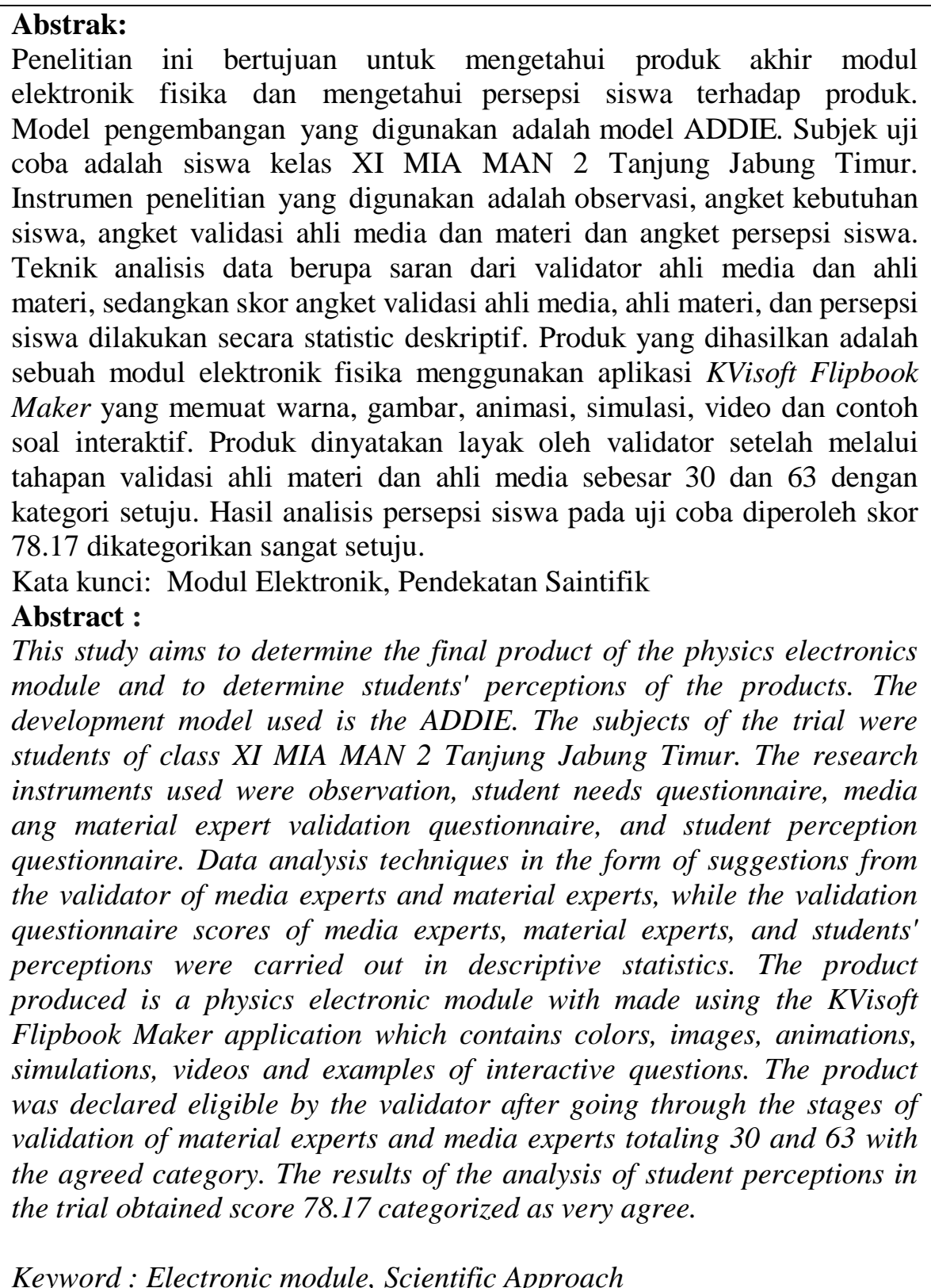 \\
\hline
\end{tabular}




\section{Pendahuluan}

Dalam Kurikulum 2013, proses pembelajaran merupakan salah satu elemen dari standar proses yang mengalami perubahan guna pencapaian keberhasilan pembelajaran dan pembentukan kompetensi siswa.Adapun isi dari standar proses menurut Permendikbud No. 65 Tahun 2013 menjelaskan bahwa dalam mengimplementasikan proses pembelajaran di kurikulum 2013 pada satuan pendidikan harus diselenggarakan secara interaktif, inspiratif, menyenangkan, menantang, memotivasi siswa untuk berpartisipasi aktif, serta memberikan ruang yang cukup bagi prakarsa, kreativitas, dan kemandirian sesuai dengan bakat, minat, dan perkembangan fisik serta psikologis siswa. Fisika merupakan bagian dari Ilmu Pengetahuan Alam (IPA) yang identik dengan peristiwa maupun fenomena alam sehingga penting untuk dipelajari. Fisika juga merupakan ilmu yang sangat berkaitan erat dengan kehidupan (Saripudin, 2014). Menurut Salsabila (2013) banyak siswa yang menganggap mata pelajaran fisika sebagai pelajaran paling sulit sehingga berdampak pada rendahnya hasil belajar siswa. Kesulitan yang terjadi dalam pembelajaran fisika antara lain banyak memuat hal-hal yang abstrak dan sulit dipahami.

Berdasarkan hasil observasi dan wawancara yang peneliti lakukan terhadap 27 siswa dan seorang guru fisika di MAN 2 Tanjung Jabung Timur pada hari Rabu 08 Februari 2017 tentang pembelajaran fisika, diketahui bahwa bahan ajar fisika yang terdapat di MAN 2 Tanjung Jabung Timur tidak cukup membantu siswa untuk melakukan pembelajaran secara mandiri. Dalam proses pembelajaran, guru Fisika di sekolah tersebut beranggapan bahwa penggunaan bahan ajar belum maksimal untuk membantu siswa dalam memahami konsep Fisika. Hal ini menyebabkan siswa merasa kurang termotivasi untuk mempelajari Fisika Dari hasil observasi juga diketahui bahwa $70 \%$ siswa mengalami kesulitan dalam mempelajari materi fisika dan bahan ajar yang digunakan hanyalah buku paket, $88 \%$ siswa menyatakan alat peraga sebagai penunjang kegiatan belajar fisika, $92 \%$ siswa membutuhkan sumber belajar lain untuk menunjang proses pembelajaran fisika dan 92\% siswa menyetujui pembuatan modul elektronik sebagai penunjang pembelajaran fisika.Berkaitan dengan permasalahan di atas, maka perlu dikembangkan sebuah bahan ajar yang dapat menarik perhatian siswa, menimbulkan motivasi siswa dan meningkatkan pemahaman konsep siswa dalam kegiatan belajar mengajar fisika.

Salah satu solusi untuk mengatasi permasalahan di atas adalah dengan mengembangkan bahan ajar yang memanfaatkan kemajuan tekhnologi di era globalisasi ini. Pembelajaran fisika tidak lagi menjadi pelajaran yang ditakuti siswa karena penyampaian pembelajaran fisika dapat berupa alat peraga, demonstrasi, praktek di laboratorium, dan pemanfaatan IT untuk menjadi media pembelajaran fisika yang menarik, efektif dan efisien. Media pembelajaran merupakan komponen penting dalam sebuah pembelajaran, media pembelajaran dapat menjadi sumber acuan selain materi yang disampaikan dari guru. Selain itu, dari media pembelajaran adalah bagian yang tidak dapat dipisahkan dari proses belajar mengajar demi tercapainya tujuan pendidikan pada umumnya dan tujuan pembelajaran di sekolah pada khususnya (Arsyad, 2011).

Salah satu media pembelajaran yang dapat digunakan untuk memahami materi adalah modul. Implementasi kurikulum 2013 menekankan pemanfaatan IT untuk media pembelajaran. Oleh karena itu, pembelajaran harus sesuai dengan perkembangan teknologi yang sekarang ini sudah merambah ke berbagai bidang, salah satunya adalah bidang pendidikan. Banyak cara yang ditempuh untuk meningkatkan kompetensi dan profesionalisme seorang guru/ tenaga pendidik. Salah satunya adalah mengembangkan bahan ajar yang dapat memotivasi siswa agar lebih aktif dan kreatif dengan menggunkan software tertentu yang dapat menghasilkan suatu bahan ajar danmedia pembelajaran yang dapat dipelajari secara mandiri dan menarik seperti modul elektronik (Susanti, 2015).

Modul elektronik (e-modul) didefenisikan sebagai sebuah bentuk penyajian bahan belajar mandiri yang disusun secara sistematis ke dalam unit pembelajaran terkecil untuk mencapai tujuan pembelajaran tertentu, yang disajikan dalam format elektronik, dimana disetiap kegiatan pembelajaran didalamnya dihubungkan dengan link-link sebagai navigasi yang membuat peserta didik menjadi lebih interaktif dengan program, 
dilengkapi dengan penyajian video tutorial, animasi dan audio untuk memperkaya pengalaman belajar (Satriawati, 2015). Pengertian modul elektronik menurut Prasetiyowati (2015) adalah bahan ajar mandiri yang disusun secara sistematis ke dalam pembelajaran terkecil untukmencapai tujuan pembelajaran tertentu yang disajikan dalam bentuk elektronik yang bersifat Self Instruction, Self Contained,Stand Alone, Adaptif,danUser Friendly yang memuat satu materi pembelajaran. Siswa diharapkan lebih utama dalam memanfaatkan modul elektronik.

Modul elektronik dengan pendekatan saintifik dapat membantu siswa dalam mengaitkan materi pembelajaran dengan kehidupan nyata. Pembelajaran dengan modul elektronik ini akan mempermudah siswa dalam memahami materi yang diajarkan terutama materi getaran harmonis. Materi ini erat kaitannya dengan percobaan secara langsung di laboratorium fisika, namun karena terkendala alokasi waktu yang kurang dan alat praktikum yang tidak mencukupi, maka modul elektronik ini akan sangat membantu siswa dalam mempelajari materi Getaran Harmonis. Hal ini dapat dilihat dari penelitian terdahulu seperti, Suryani (2016) dengan skripsinya yang berjudul "Pengembangan modul pembelajaran menggunakan Learning Content Development System (LCDS) pada materi gerak harmonik sederhana". Modul pembelajaran yang dikembangkan memiliki kualitas menarik dengan skor kemenarikan 3,18, mudah digunakan dengan skor kemudahan 3,07, dan bermanfaat dengan skor kemanfaatan 3,22. Modul pembelajaran menggunakan LCDS untuk pembelajaran gerak harmonik sederhana sudah efektif digunakan sebagai sumber belajar dengan $80 \%$ nilai $\mathrm{N}$-gain termasuk dalam klasifikasi sedang. Hayati, dkk (2015) juga pernah melakukan penelitian pengembangan media pembelajaran berbasis flipbook dengan judul "Pengembangan Media Pembelajaran Flipbook Fisika Untuk Meningkatkan Hasil Belajar Peserta Didik". Pada penelitian ini, Uji coba pada pengguna dilakukan di SMAN 22 Jakarta tanpa revisi. Berdasarkan hasil uji coba pada pendidik sebagai pengguna didapatkan rata-rata persentase dari semua indikator yaitu 99,38\% dengan interpretasi sangat baik. Dari hasil penelitian di atas maka dapat disimpulkan bahwa modul elektronik yang dikembangkan layak digunakan sebagai media pembelajaran dalam proses kegiatan pembelajaran. Tetapi masih ada yang perlu diperbaiki seperti tampilan agar lebih menarik serta dapat membuat modul elektronik dengan materi lain dengan lebih aplikatif, interaktif, dan bermanfaat.

Modul elektronik dikembangkan dengan menggunakan Kvisoft Flipbook Maker. Menurut Susanti (2015) Kvisoft FlipBook Maker adalah software untuk membuat sebuahe-book, e-catalog, e-brousher, epresentations dengan cukup mudah. Pengguna hanya tinggal menambahkan dokumen PDF, JPG, PNG, BMP, atau Jenis video baik SWF, MP4, dan mengolahnya dengantemplate yang telah disediakan agar menghasilkan suatu flip bookyang menarik untuk dipresentasikan.File PDF merupakan file yang memiliki ukuran lebih kecil dari file doc dan aman terhadap serangan virus. Keunggulan lain file PDF adalah file ini dapat diupload ke internet dengan mudah sehingga dapat diakses oleh semua siswa.Ada kalanya dalam membuat modul/handout berisi materi ajar dan soal-soal latihan, para guru menggunakan file-file PDF. Namun, seiring perkembangan waktu tampilan file-file PDF saat ini cenderung biasa-biasa saja. Software Kvisoft Flipbook Makerdapat mengubah file-file pdf, file gambar menjadi lebih menarik untuk presentasi. Software ini dapat digunakan agar presentasi terlihat lebih menarik dengan efek musik yang tampil dengan file $S W F$ ataupun $E X E$, sehingga siswa dapat belajar dengan lebih menyenangkan. File-file ini juga dapat dimasukkan ke dalam TABLET, sehingga dapat ditampilkan lebih menarik.

Modul Elektronik perlu dikembangkan dengan pendekatan, metode ataupun model agar lebih terarah dan terstruktur karena adanya langkah-langkah dalam pembelajaran. Salah satu pendekatan yang diterapkan dalam Kurikulum 2013 adalah pendekatan saintifik. Pendekatan saintifik merupakan pendekatan yang terdapat dalam kurikulum 2013 sebagai pendekatan baru dan harus digunakan oleh seorang guru dalam menyampaikan materi ajar yang disajikan melalui proses mengamati, menanya, mencoba, mengasosiasi, dan mengkomunikasikan. Proses pembelajaran dengan menggunakan pendekatan saintifik akan memudahkan siswa ketika pendekatan tersebut dituangkan melalui media 
pembelajaran berupa modul elektronik. Modul elektronik menuntun siswa untuk belajar mandiri sehingga siswa mampu mempunyai inisiatif dengan atau tanpa bantuan orang lain untuk mengetahui kebutuhan belajarnya sendiri, merumuskan atau menentukan tujuan belajarnya, mengindentifikasi sumber-sumber belajar, melaksanakan strategi belajarnya, dan mengevaluasi hasil belajarnya sendiri (Suryani, 2016).

Modul elektronik dengan pendekatan saintifik dapat membantu siswa dalam mengaitkan materi pembelajaran dengan kehidupan nyata. Pembelajaran dengan modul elektronik ini akan mempermudah siswa dalam memahami materi yang diajarkan terutama materi getaran harmonis. Materi ini erat kaitannya dengan percobaan secara langsung di laboratorium Fisika, namun karena terkendala alokasi waktu yang kurang dan alat praktikum yang tidak mencukupi, maka modul elektronik ini akan sangat membantu siswa dalam mempelajari materi getaran harmonis.

\section{Metode Penelitian}

Jenis Penelitian

Jenis penelitian ini adalah penelitian dan pengembangan (Research and Development).Model pengembangan yang digunakan adalah model ADDIE yaitu singkatan dari analyze(analisis), design (desain), development (pengembangan), implementation (implementasi), dan evaluate (evaluasi) (Branch ,2009). Model ADDIE digunakan karena model ADDIE bertujuan untuk membuat bahan ajar.

Waktu dan Temapat Penelitian

Penelitian dilaksanakan di MAN 2 Tanjung Jabung Timur pada tanggal 23 Desember 2017.

\section{Subjek Penelitian}

Subjek penelian ini terdiri dari siswa kelas XI MIA MAN 2 Tanjung Jabung Timur. Tujuan dilakukan penelitian di kelas XI MIA yaitu untuk melihat persepsi siswa terhadap modul elektronik.

Prosedur Pengembangan

Modul elektronik yang dikembangkan menggunakan model ADDIE yang terdiri atas 5 tahap yaitu, analisis (analize), desain (design), pengembangan (development), pelaksanaan (implementation), dan evaluasi (evaluation). Namun pada penelitian ini, peneliti membatasi tahap implementasi karena kekurangan waktu dan biaya.

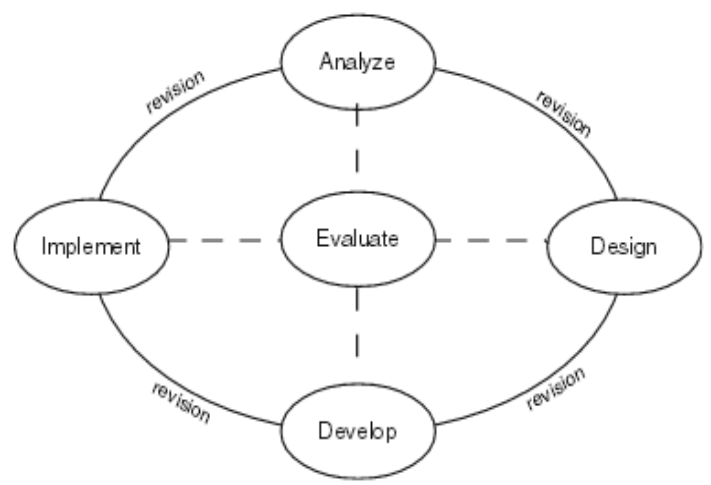

Gambar 1. Tahap Pengembangan Model ADDIE (Sumber: Branch 2009)

\section{1) Analisis}

Tahap pertama yang dilakukan dalam mengembangkan modul elektronik fisika yaitu analisis. Analisis dilakukan dengan observasi awal untuk mengidentifikasi fakta-fakta yang ada dalam proses pembelajaran.Tahapan analisis yang dilakukan untuk mengidentifikasi fakta-fakta yaitu memvalidasi kesenjangan kinerja, menetapkan tujuan, analisis siswa, analisis kebutuhan dan sumber daya yang tersedia dan menyusun rencana kerja.

2) Desain

Pada tahapan desain, peneliti membuat rancangan dari modul elektronikyang akan dikembangkan. Modul elektronikdirancang sesuai dengan hasil analisis yang telah dilakukan, dimana rancangan disesuaikan dengan kebutuhan siswa, silabus dan indikator pembelajaran yang ingin dicapai. Sebelum di validasi dengan validasi ahli media dan validasi ahli materi, maka harus dibuat desain awal produk. Adapun desain awal modul elektronikyang akan dikembangkan dapat dilihat di bawah ini. 
Tabel 1. Perancangan awal modul elektronik fisika

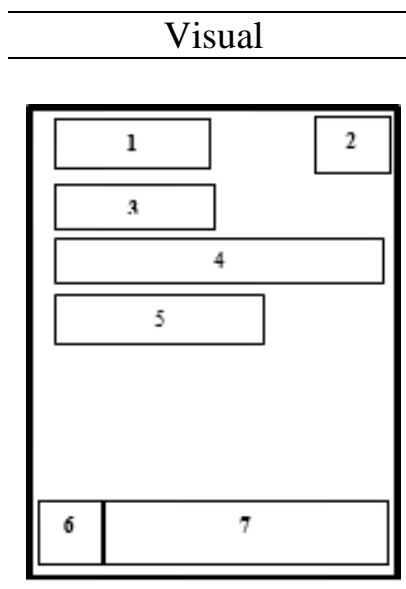

Halaman Cover

1. Nama penulis.

2. Logo kurikulum 2013.

3. Berisi kata

"MODUL".

4. Judul materi yaitu "GETARAN

HARMONIS".

5. Jenjang pendidikan SMA/MA dan semester.

6. Logo Universitas Jambi.

7. Berisi tulisan nama prodi, jurusan dan universitas.

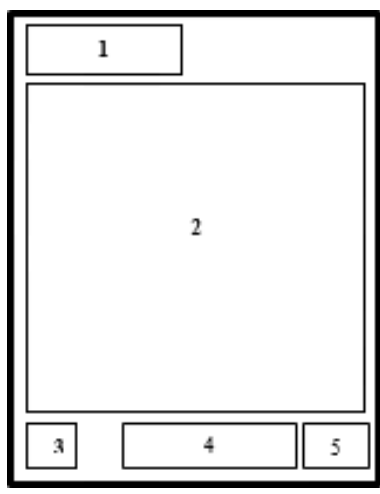

Halaman Kata

Pengantar

1. Berisi judul yaitu "Kata Pengantar".

2. Berisi kata pengantar.

3. Logo home.

4. Berisi kata "Modul Getaran Harmonis"

5. Nomor halaman.

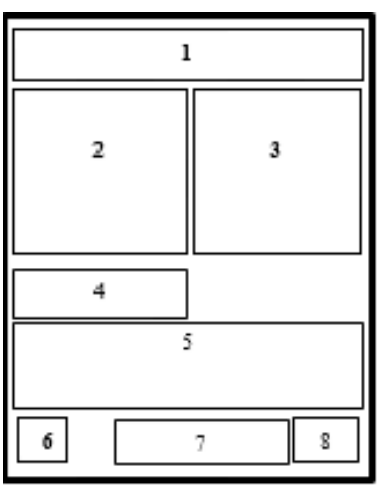

Halaman Pembelajaran

(Tujuan Pembelajaran)

1. Judulsub materi.

2. Gambar yang berkaitan dengan materi.

3. Gambar yang berkaitan dengan materi.

4. Judul "Tujuan Pembelajaran".

5. Tujuan pembelajaran

6. Logo home.

7. Berisi kata "Modul Getaran Harmonis"

8. Nomor halaman.

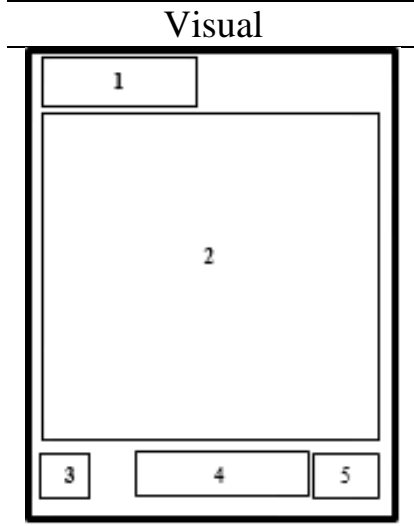

Keterangan

Halaman Pembelajaran

(Materi)

1. Berisi kolom tentang langkah saintifik.

2. Materi, equation, foto, video, simulasi dan animasi.

3. Logo home.

4. Berisi kata "Modul Getaran Harmonis"

5. Nomor halaman.

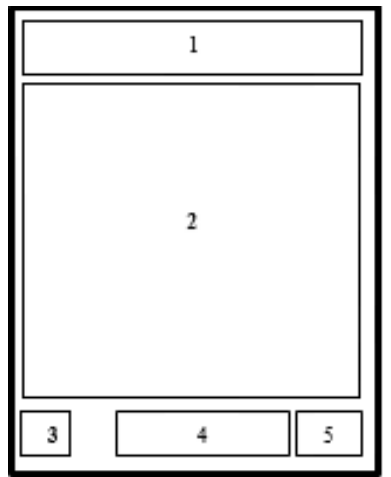

Halaman Pembelajaran (Contoh Soal)

1. Judul "Contoh Soal".

2. Contoh soal.

3. Berisi logo home.

4. Berisi kata "Modul Getaran Harmonis".

5. Nomor halaman.

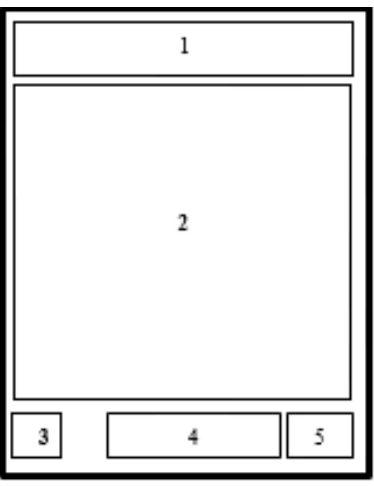

Halaman Pembelajaran (Rangkuman)

1. Judul "Rangkuman".

2. Berisi rangkuman tentang materi.

3. Berisi logo home.

4. Berisi kata "Modul Getaran Harmonis".

5. Nomor halaman.

\section{3) Pengembangan (Development)}

Tahap pengembangan merupakan tahap pembuatan modul elektronik fisika menggunakan aplikasi Kvisoft flipbook maker. Modul elektronik yang dibuat disesuaikan dengan desain yang telah dirancang. Hal-hal yang terlebih dahulu dilakukan dalam pembuatan modul elektronik yaitu mengumpulkan materi pembelajaran yang akan disajikan, gambar, video, dan animasi yang berkaitan dengan materi. Untuk menambah ketertarikan siswa dalam mempelajari mata pelajaran fisika pada pokok bahasan getaran harmonis. Setelah seluruh bahan yang diperlukan terkumpul, maka 
langkah selanjutnya yang dilakukan adalah membuat modul elektronik fisika menggunakan aplikasi pengembangnya yaitu kvisoft flipbook maker.

4) Evaluasi

Evaluasi pada pengembangan ini ada disetiap tahapan mulai dari analisis, desain dan pengembangan. Evaluasi digunakan untuk menilai proses dan produk yang dibuat.

\section{Uji Coba Produk}

Uji coba produk merupakan tahap penilaian dengan tujuan untuk mengetahui apakah produk yang dihasilkan telah layak digunakan dalam kegiatan pembelajaran atau tidak dengan mempertimbangkan kesesuaian antara produk media dengan pengguna dalam menyelesaikan masalah pada materi fisika getaran harmonis serta untuk mengetahui sejauh mana media yang dihasilkan dapat mencapai tujuan pembelajaran yang diinginkan.Uji coba produk dilakukan setelah produk divalidasi oleh ahli media dan ahli materi kemudian diujicobakan kepada 30 siswa kelas XI MIA MAN 2 Tanjung Jabung Timur.

\section{Jenis Data}

Pada penelitian pengembangan ini, jenis data yang diambil yaitu data kuantitatif dan kualitatif. Data kuantitatif diperoleh dari persepsi siswa berupa angket terhadap modul elektronik berbasis Pendekatan Saintifik yang telah dihasilkan. Sedangkan data kualitatif berupa saran dan tanggapan dari validasi tim ahli terhadap modul elektronik berbasis Pendekatan Saintifik.

\section{Instrumen Pengumpulan Data}

Adapun instrumen pengumpulan data yang digunakanantara lain.

1. Observasi

Observasi biasa diartikan sebagai pengamatan dan pencatatan secara sistematik terhadap unsur-unsur yang nampak dalam suatu gejala pada objek penelitian (Widoyoko, 2016). Metode observasi ini digunakan untuk melihat dan mengamati secara langsung keadaan di lapangan agar memperoleh gambaran yang lebih luas tentang permasalahan yang akan dilakukan.
2. Angket Kebutuhan siswa

Pada angket kebutuhan siswa berisikan tentang aspek-aspek yang berhubungan dengan keadaan pembelajaran fisika serta hal-hal yang dibutuhkan dalam pembelajaran fisika.

3. Angket Validasi Ahli Materi

Pada angket validasi ahli media berisikan tentang aspek-aspek yang berhubungan dengan media yang telah dikembangkan meliputi desain sampul modul, desain isi modul, desain software modul, komponen penyajian, dan kemudahan pengoperasian.

Tabel 2. Angket validasi ahli materi

\begin{tabular}{clcc}
\hline No. & \multicolumn{1}{c}{ Indikator Pencapaian } & $\begin{array}{c}\text { Jumlah } \\
\text { Butir }\end{array}$ & $\begin{array}{c}\text { Nomor } \\
\text { Butir }\end{array}$ \\
\hline $\begin{array}{l}\text { Kesesuaian materi } \\
\text { dengan tujuan }\end{array}$ & 1 & 1 \\
& $\begin{array}{l}\text { pembelajaran. } \\
\text { Ketepatan materi dan isi. }\end{array}$ & 5 & $2,3,4$, \\
2. & Kemuktahiran materi. & 1 & 5,6 \\
3. & Komponen kebahasaan. & 3 & $8,9,10$ \\
4. & Kompan \\
\hline
\end{tabular}

4. Angket Validasi Ahli Media

Pada angket validasi ahli materi berisikan tentang aspek-aspek yang berhubungan dengan materi modul elektronik meliputi kesesuaian materi dengan tujuan pembelajaran, ketepatan materi dan isi,dan komponen kebahasaan.

Tabel 3. Angket validasi ahli media

\begin{tabular}{cccc}
\hline No. & Indikator Pencapaian & $\begin{array}{c}\text { Jumlah } \\
\text { Butir }\end{array}$ & $\begin{array}{c}\text { Nomor } \\
\text { Butir }\end{array}$ \\
\hline 1. & Desain sampul modul & 4 & $1,2,3,4$ \\
2. & Desain isi modul & 8 & $\begin{array}{c}5,6,7,8, \\
9,10,11, \\
12\end{array}$ \\
& Desain software & 4 & $13,14,15$, \\
3. & modul & & 16 \\
4. & Komponen penyajian & 4 & $17,18,19$, \\
5. & Kemudahaan & 1 & 20 \\
\hline
\end{tabular}

\section{Angket Persepsi siswa}

Pada angket persepsi siswa berisikan tentang aspek-aspek yang berhubungan dengan modul elektronik yang telah dikembangkan meliputi desain sampul modul, desain isi modul, desain software modul, komponen penyajian, kemudahan pengoperasian, dan komponen kebahasaan. 
Tabel 4. Angket persepsi siswa

\begin{tabular}{|c|c|c|c|}
\hline No. & Indikator Pencapaian & $\begin{array}{c}\text { Jumlah } \\
\text { Butir } \\
\end{array}$ & $\begin{array}{c}\text { Nomor } \\
\text { Butir }\end{array}$ \\
\hline 1. & Desain sampul modul & 4 & $\begin{array}{c}1,2,3 \\
4\end{array}$ \\
\hline 2. & Desain isi modul & 7 & $\begin{array}{c}5,6,7 \\
8,9, \\
10,11\end{array}$ \\
\hline 3. & Desain software modul & 4 & $\begin{array}{l}12,13, \\
14,15\end{array}$ \\
\hline 4. & Komponen penyajian & 1 & 16 \\
\hline 5. & $\begin{array}{l}\text { Kemudahaan } \\
\text { pengoperasian }\end{array}$ & 1 & 17 \\
\hline 6. & Komponen kebahasaan & 5 & $\begin{array}{c}18,19, \\
20,21, \\
22\end{array}$ \\
\hline
\end{tabular}

Analisis Instrumen Penelitian

a. Analisis validitas

Validitas adalah suatu ukuran yang menunjukkan tingkat-tingkat kesahihan suatu instrumen. Terdapat dua jenis validitas yang sering digunakan yaitu validitas logis dan empiris. Namun dalam penelitian ini penulis lebih mengutamakan penggunaan validitas logis. Dikatakan validitas logis karena validitas ini diperoleh dengan suatu usaha hati-hati melalui cara-cara yang benar sehingga menurut logika akan dicapai suatu tingkat validitas yang dikehendaki. Dengan demikian, validitas logis tidak perlu diuji kondisinya. Adapun karakteristik yang dinilai dalam validitas ini yaitu: isi, konstruk dan bahasa.

b. Analisis reliabilitas

Reliabilitas menunjuk pada satu pengertian bahwa sesuatu instrumen cukup dapat dipercaya untuk digunakan sebagai alat pengumpul data karena instrumen tersebut sudah baik.Dalam penelitian ini untuk mengukur reliabilitas ditentukan dengan rumus Cronbach Alphasebagai berikut (Arikunto, 2013).

$$
r_{11}=\left(\frac{n}{n-1}\right)\left(1-\frac{\Sigma \sigma_{i}^{2}}{\sigma_{t}^{2}}\right)
$$

Dengan:

$$
\sigma_{t}^{2}=\frac{\Sigma X^{2}-\frac{(\Sigma X)^{2}}{N}}{N}
$$

Keterangan:

$r_{11} \quad=$ indeks korelasi (harga reliabilitas)

$n \quad$ = banyaknya butir soal
$\Sigma \sigma_{i}^{2} \quad=$ jumlah varians butir.

$\sigma_{t}^{2} \quad=$ varians total.

$N \quad$ = banyak peserta yang mengisi angket

$X \quad=$ skor yang diberikan

\section{Teknik Analisis Data}

1. Analisis data kualitatif

Teknik analisis data dalam penelitian kualitatif yang berupa observasi dan saran dari validator dilakukan secara deskriptif kualitatif.

a. Observasi

- $\quad$ Reduksi data

Observasi dilakukan dengan cara mengumpulkan data secara langsung dengan menggunakan angket kebutuhan siswa yang terdiri dari 17 item pertanyaan,data yang didapat dari 17 item pertanyaain direduksi menjadi beberapa item pertanyaan yangsesuai dengan permasalahan penelitian yaitu pengembagan bahan ajar yang berupa modul elektronik.

- $\quad$ Penyajian data

Data yang telah direduksi disajikan dalam bentuk presentase dan dilihat seberapa besar tanggapan yang mendukung ataupun yang menolakakan pengembangan modul elektronik.

- Penarikan kesimpulan

Berdasarkan data yang telah disajikan maka dapat ditarik kesimpulan bahwa responden menyetujui ataupun menolak akan pengembangan modul elektronik, data kualitatif pada tahapan ini disajikan dalam tahap analyze.

b. Saran dari validator ahli media dan ahli materi

- $\quad$ Reduksi data

Saran dari validator ahli media dan ahli materi ditulisterlebih dahulu dalam bentuk teks selanjutnya data yang berbentuk teks direduksi misalnya per indikator pada angket validasi ahli media dan ahli materi.

- Penyajian data

Data yang telah direduksi selanjutnya disajikan dalam bentuk deskripsi, dari deskripsi tersebut maka dapat dilihat bahwa validator menyatakan layak atau belum layak modul elektronik dapat digunakan sebagai sumber belajar mandiri bagi siswa.(2)

Penarikan kesimpulan

Setelah data disajikan maka ditarik kesimpulan bahwa validator menyatakan layak atau belum layak digunakan sebagai salah satu 
sumber belajar yang bisa digunakan oleh siswa, data kualitatif pada tahapan ini disajikan dalam tahap development.

2. Analisis data kuantitatif

Teknik analisis data dalam penelitian kuantitatif yang berupa skor validasi ahli media, validasi ahli materi dan persepsi siswa dilakukan secara statistik deskriptif dan disajikan dalam tabel. Langkah-langkah menganalisis data kuantitatif tersebut adalah sebagai berikut:

a. Mengkuantitatifkan hasil checking dengan memberi skor sesuai dengan bobot yang telah ditentukan sebelumnya.

Tabel 5. Interval Skala Likert

\begin{tabular}{cc}
\hline Respons & Bobot Skor \\
\hline Sangat Setuju & 4 \\
Setuju & 3 \\
Tidak Setuju & 2 \\
Sangat Tidak Setuju & 1 \\
\hline
\end{tabular}

(Sumber: Direktorat Pembinaan SMA, 2010)

b. Menentukan modus

Modus merupakan tekhnik penjelasan kelompok yang didasarkan atas nilai yang sedang popular (yang sedang menjadi mode) atau nilai yang sering muncul dalam kelompok tersebut.

c. Menentukan median

Median adalah salah satu teknik penjelasan kelompok yang didasarkan atas nilai tengah dari kelompok data yang telah disusun urutannya dari yang terkecil sampai yang terbesar, atau sebaliknya dari yang terbesar sampai yang terkecil.

d. Menentukan skor rata-rata indikator yang diberikan berdasarkan penilaian dari validasi ahli media, validasi ahli materi, dan persepsi siswa.

$$
\bar{X}=\frac{\sum X}{n}
$$

Keterangan:

$$
\begin{array}{ll}
\bar{X} & =\text { Mean } \\
\sum X & =\text { jumlah skor jawaban } \\
& \text { responden (validator) } \\
\mathrm{N} & =\text { jumlah responden (validator) }
\end{array}
$$

e. Menentukan varians dan standar deviasi sampel.

$$
\begin{gathered}
s^{2}=\frac{\sum(x i-\bar{x})^{2}}{(n-1)}(4) \\
s=\sqrt{\frac{\sum(x i-\bar{x})^{2}}{(n-1)}}(5)
\end{gathered}
$$

$$
\begin{array}{ll}
\text { Keterangan } \\
s & =\text { varians kelompok data } \\
s^{2} & =\text { standar deviasi kelompok } \\
\mathrm{n} & =\text { jumlah responden (validator) }
\end{array}
$$

f. Mengidentifikasi kecenderungan ubahan setiap sub variabel digunakan rata-rata ideal (Xi) dan standar deviasi ideal (SDi), dapat dihitung dengan acuan norma yaitu:

Xideal $=\frac{1}{2}$ (skor tertingi + skor terendah)

SDideal $=\frac{1}{6}$ (skor tertinggi - skor terendah)

g. Kemudian setiap sub variabel dikategorikan menjadi empat kategori dan diubah menjadi data kualitatif sebagai berikut :

Tabel 6. Rentang Skor dan Kriteria Kualitatif

$$
\begin{array}{cc}
\text { Rentang Skor } & \text { Kriteria } \\
X i+1,5 S D i \leq \bar{X} \leq X i+3,0 S D i & \text { Sangat } \\
& \text { Setuju } \\
X i+0 S D i \leq \bar{X}<X i+1,5 S D i & \text { Setuju } \\
X i-1,5 S D i \leq \bar{X}<X i+0 S D i & \text { Tidak } \\
& \text { Setuju } \\
X i-3 S D i \leq \bar{X}<X i-1,5 S D i & \text { Sangat } \\
& \text { tidak } \\
& \text { Setuju }
\end{array}
$$

(Sumber: Direktorat Pembinaan SMA, 2010)

\section{Hasil dan Pembahasan}

Modul elektronik didesain dan dikembangkan berdasarkan hasil yang diperoleh dari tahapan observasi awal sampai pada tahapan desain. Untuk menyesuaikan apa yang dibutuhkan siswa dengan apa yang telah dikembangkan, maka dilakukan validasi sebanyak 2 kali. Validasi yang dilakukan yaitu validasi materi dan validasi media. Validasi dilakukan oleh 2 orang dosen Pendidikan Fisika Universitas Jambi. Validator akan memberikan saran, kritikan terhadap modul elektronik yang dikembangkan. Validasi 
dilakukan sampai validator menyatakan bahwa modul elektronik telah layak digunakan tanpa revisi.

\section{Validasi Materi}

Pada validasi materi tahap I, berdasarkan angket yang diberikan, validator menyarankan:

a) Menyesuaikan contoh soal yang digunakan dengan materi dan dapat mengukur kompetensi keberhasilan siswa.

b) Menyesuaikan gambar dan grafik dengan materi.

c) Menyesuaikan animasi dan video dengan materi.

d) Menggunakan Bahasa yang lebih komunikatif agar siswa lebih mengerti.

Hasil validasi ahli materi tahap I dapat dilihat pada tabel 7 berikut.

Tabel7. Validasi ahli materi tahap I

\begin{tabular}{ccc}
\hline Indikator & Skor & Ket. \\
\hline $\begin{array}{c}\text { Kesesuaian } \\
\text { materi dengan } \\
\text { tujuan }\end{array}$ & 3 & Setuju \\
$\begin{array}{c}\text { pembelajaran } \\
\text { Ketepatan materi } \\
\text { dan isi }\end{array}$ & 12 & $\begin{array}{c}\text { Tidak } \\
\text { Setuju }\end{array}$ \\
$\begin{array}{c}\text { Kemutakhiran } \\
\text { Materi }\end{array}$ & 3 & Setuju \\
$\begin{array}{c}\text { Komponen } \\
\text { kebahasaan } \\
\text { Indikator }\end{array}$ & 8 & Setuju \\
Keseluruhan & 26 & Setuju \\
\hline
\end{tabular}

Setelah seluruh saran dari validator diperbaiki, maka pada validasi tahap kedua semua validator menyatakan modul elektronik telah layak dan dapat digunakan. Hasil validasi ahli materi tahap II dapat dilihat pada tabel 8berikut.

Tabel 8. Validasi ahli materi tahap II

\begin{tabular}{ccc}
\hline Indikator & Skor & Ket. \\
\hline $\begin{array}{c}\text { Kesesuaian } \\
\text { materi dengan } \\
\text { tujuan }\end{array}$ & 3 & Setuju \\
pembelajaran & & Setuju \\
$\begin{array}{c}\text { Ketepatan materi } \\
\text { dan isi }\end{array}$ & 16 & Setuju \\
$\begin{array}{c}\text { Kemutakhiran } \\
\text { Materi }\end{array}$ & 3 & Setuju \\
$\begin{array}{c}\text { Komponen } \\
\text { kebahasaan }\end{array}$ & 9 &
\end{tabular}

Indikator

Keseluruhan

28

Setuju

2. Validasi Media

Pada validasi media tahap I, berdasarkan angket yang diberikan, validator menyarankan:

a) Menggunakan gambar yang lebih menarik dan jelas.

b) Membuat tata letak tulisan pada modul menjadi lebih rapi.

c) Menyesuaikan Gambar dan grafik dengan materi

d) Menggunakan warna layout yang relevan

e) Menggunakan warna yang menarik dan polos saja.

f) Memperjelas suara pada tampilan $e$ modul.

Hasil validasi ahli media tahap I dapat dilihat pada tabel 9 berikut.

Tabel 9. Validasi ahli media tahap I

\begin{tabular}{|c|c|c|}
\hline Indikator & Skor & Ket. \\
\hline $\begin{array}{l}\text { Desain Sampul } \\
\text { Modul }\end{array}$ & 11 & Setuju \\
\hline Desain Isi Modul & 22 & Setuju \\
\hline $\begin{array}{c}\text { Desain Software } \\
\text { Modul }\end{array}$ & 9 & $\begin{array}{l}\text { Tidak } \\
\text { Setuju }\end{array}$ \\
\hline $\begin{array}{c}\text { Komponen } \\
\text { Penyajian }\end{array}$ & 12 & Baik \\
\hline $\begin{array}{l}\text { Kemudahan } \\
\text { pengoperasian }\end{array}$ & 3 & Baik \\
\hline $\begin{array}{l}\text { Indikator } \\
\text { keseluruhan }\end{array}$ & 57 & Baik \\
\hline
\end{tabular}

Setelah seluruh saran dari validator diperbaiki, maka pada validasi tahap kedua semua validator menyatakan modul elektronik telah layak dan dapat digunakan. Hasil validasi ahli media tahap II dapat dilihat pada tabel 10 berikut.

Tabel 10. Validasi ahli media tahap II

\begin{tabular}{|c|c|c|}
\hline Indikator & Skor & Ket. \\
\hline $\begin{array}{l}\text { Desain Sampul } \\
\text { Modul }\end{array}$ & 12 & Setuju \\
\hline Desain Isi Modul & 24 & $\begin{array}{l}\text { Sangat } \\
\text { Setuju }\end{array}$ \\
\hline $\begin{array}{c}\text { Desain Software } \\
\text { Modul }\end{array}$ & 12 & Setuju \\
\hline $\begin{array}{c}\text { Komponen } \\
\text { Penyajian }\end{array}$ & 12 & Setuju \\
\hline $\begin{array}{l}\text { Kemudahan } \\
\text { pengoperasian }\end{array}$ & 3 & Setuju \\
\hline $\begin{array}{l}\text { Indikator } \\
\text { keseluruhan }\end{array}$ & 63 & $\begin{array}{l}\text { Sangat } \\
\text { Setuju }\end{array}$ \\
\hline
\end{tabular}


Setelah dilakukan validasi oleh tim ahli, langkah selanjutnya yaitu melakukan uji coba kelayakan modul elektronik kepada siswa menggunakan angket persepsi siswa. Sekolah yang dipilih sebagai tempat uji coba adalah MAN 2 Tanjung Jabung Timur. Adapun responden yang dipilih yaitu siswa kelas XI MIA untuk menentukan persepsi siswa terhadap modul elektronik yang dikembangkan. Tahapan uji coba pertama kali dilakukan dengan uji coba validitas dan reliabilitas kuisioner. Sebelum dilakukan uji reliabilitas terhadap angket yang digunakan untuk melihat persepsi siswa, angket tersebut harus memiliki validitas terlebih dahulu. Validitas yang digunakan adalah validitas logis. Validitas logis adalah dimana angket disusun berdasarkan kisi-kisi dan dengan usaha yang sangat hati-hati sehingga secara logika instrumen itu dicapai menurut validitas yang dikehendaki. Angket dianggap sudah memiliki validitas logis setelah didapat nilai reliabilitas angket yang digunakan, kemudian dilakukan uji coba untuk melihat kelayakan modul elektronik.

Tabel 11. Analisis data persespsi siswa

\begin{tabular}{cc}
\hline Rata-rata & 78.17 \\
Nilai Maksimum & 88 \\
Nilai minimum & 22 \\
Standar Deviasi & 11 \\
\hline
\end{tabular}

Uji coba dilakukan di kelas XI MIA MAN 2 Tanjung Jabung Timur dimana data yang diambil adalah Persepsi siswa terhadap modul elektronik yang telah dikembangkan.

Berdasarkan angket yang telah disebarkan, maka diperoleh hasil data sebagai berikut:

Tabel 12. Hasil persepsi siswa terhadap pengembangan modul elektronik

\begin{tabular}{|c|c|c|}
\hline Indikator & $\begin{array}{c}\text { Skor Rata- } \\
\text { rata }\end{array}$ & Ket. \\
\hline $\begin{array}{c}\text { Desain Sampul } \\
\text { Modul }\end{array}$ & 14,07 & $\begin{array}{l}\text { Sangat } \\
\text { Setuju }\end{array}$ \\
\hline Desain Isi Modul & 25,03 & $\begin{array}{l}\text { Sangat } \\
\text { Setuju }\end{array}$ \\
\hline $\begin{array}{c}\text { Desain Software } \\
\text { Modul }\end{array}$ & 13,50 & $\begin{array}{l}\text { Sangat } \\
\text { Setuju }\end{array}$ \\
\hline $\begin{array}{l}\text { Komponen } \\
\text { Penyajian }\end{array}$ & 3,50 & $\begin{array}{l}\text { Sangat } \\
\text { Setuju }\end{array}$ \\
\hline $\begin{array}{l}\text { Kemudahan } \\
\text { pengoperasian }\end{array}$ & 3,67 & $\begin{array}{l}\text { Sangat } \\
\text { Setuju }\end{array}$ \\
\hline
\end{tabular}

$\begin{array}{ccc}\begin{array}{c}\text { Komponen } \\ \text { Kebahasaan }\end{array} & 18,40 & \begin{array}{l}\text { Sangat } \\ \text { Setuju }\end{array} \\ \text { Indikator } & 78,17 & \begin{array}{l}\text { Sangat } \\ \text { Setuju }\end{array} \\ \text { keseluruhan } & & \text { S }\end{array}$

Berdasarkan tabel 12 dapat disimpulkan bahwa terlihat siswa sangat setuju dengan desain sampul modul, desain isi modul, desain software modul, komponen penyajian, kemudahan pengoperasian dan komponen kebahasaan dengan indicator keseluruhan 78,17 .

Produk yang dihasilkan adalah sebuah media pembelajaran berupa bahan ajar dengan spesifikasi antara lain modul elektronik dibuat dengan menggunakan aplikasi KVisoft Flipbook Maker, program dilengkapi dengan warna, gambar, animasi, dan video yang dapat membantu dalam penggunaannya, jenis huruf pada teks utama yang digunakan adalah Times New Roman, bagian pendahuluan berisi kompetensi dasar, deskripsi modul, alokasi waktu, prasyarat, cara menggunakan modul dan peta konsep. Bagian pembelajaran berisi tujuan pembelajaran, materi, kegiatan 5M pada pendekatan saintifik, contoh soal, latihan soal, bagian akhir modul elektronik berisi rangkuman, uji ompetensi, glosarium dan daftar pustaka.

\section{Spesifikasi}

Adapun spesifikasi produk yang diharapkan peneliti dalam pengembangan ini, yaitu:

1. Modul elektronik yang dibuat merupakan bahan ajar Fisika yang dikembangkan dengan menggunakan aplikasi Kvisoft flipbook maker.

2. Format akhir dari modul elektronik ini yaitu dalam format $s w f$.

3. Kerangka modul terdiri dari cover modul, profil editor, peta kedudukan modul, kegiatan pembelajaran per sub bab dengan contoh dan latihan soal serta tes uji kompetensi.

4. Materi getaran harmonis disajikan secara mendalam yang dilengkapi dengan persamaan yang jelas, video, gambar, grafik, animasi, simulasi, contoh soal, dan soal latihan yang dapat membantu dalam proses pembelajaran

5. Kegiatan pembelajaran dalam modul elektronik fisika menggunakan pendekatan siantifik. 
Kajian Produk Akhir

Adapun kajian produk akhir dari modul elektronik yang telah dikembangkan sebagai berikut:

\section{Cover modul elektronik}

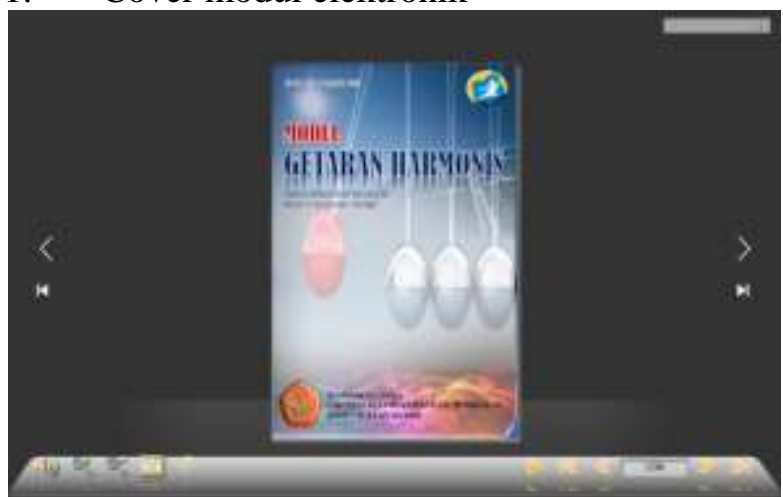

2. Profil penulis

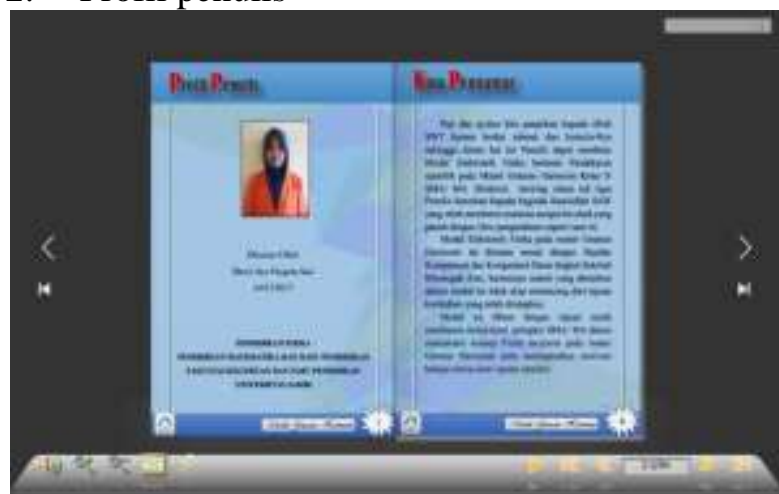

3. Kata pengantar modul elektronik

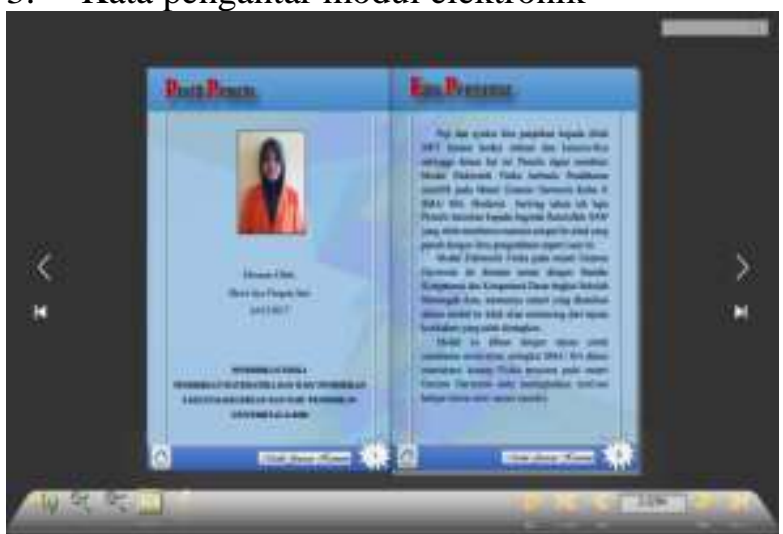

4. Daftar isi modul elektronik

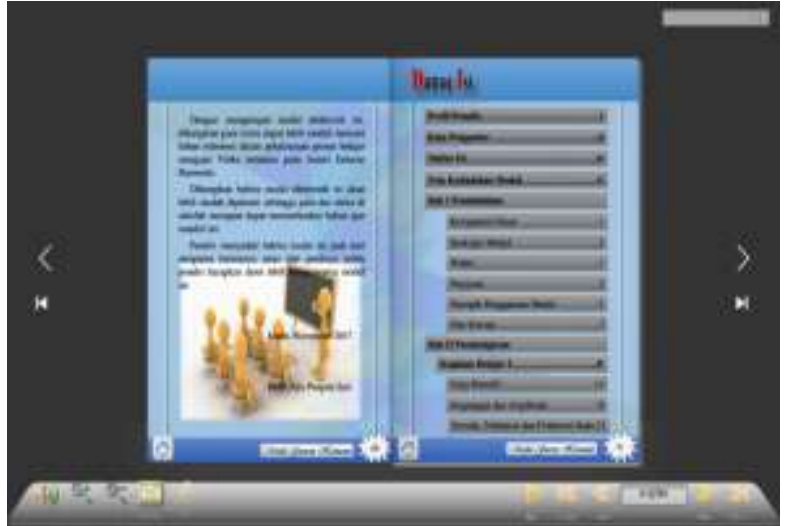

5. Peta kedudukan modul elektronik

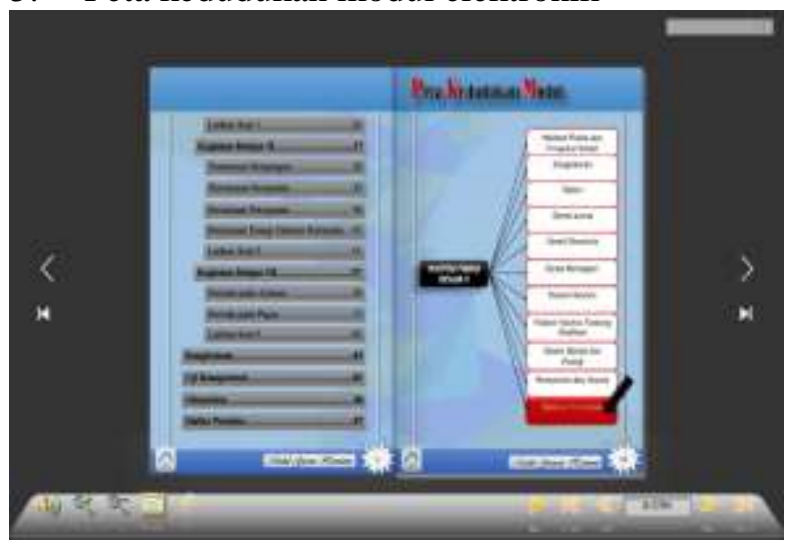

6. Pendahuluan modul elektronik

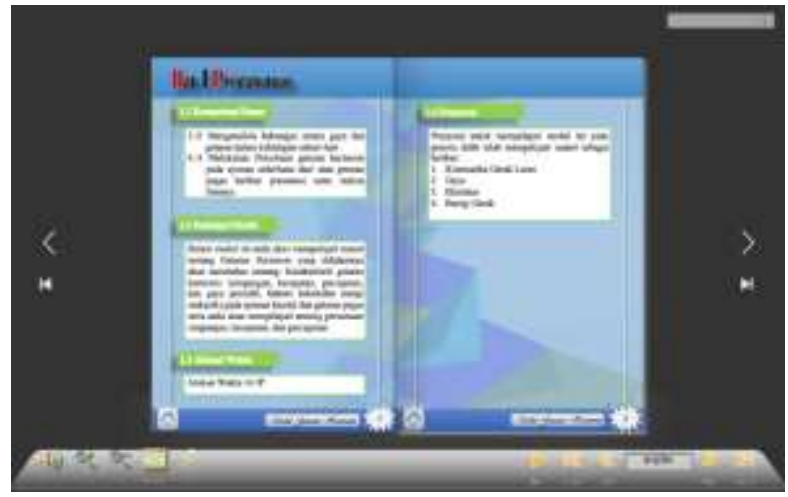

7. Petunjuk penggunaan modul elektronik

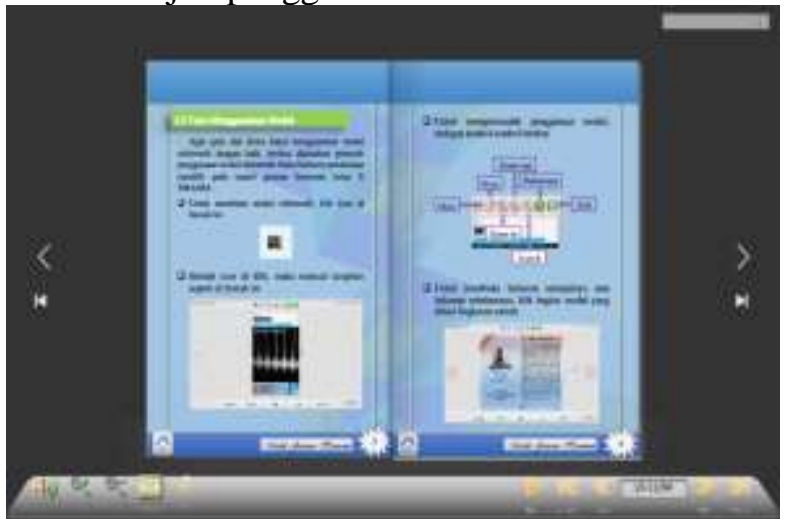


8. Bagian awal kegiatan pembelajaran

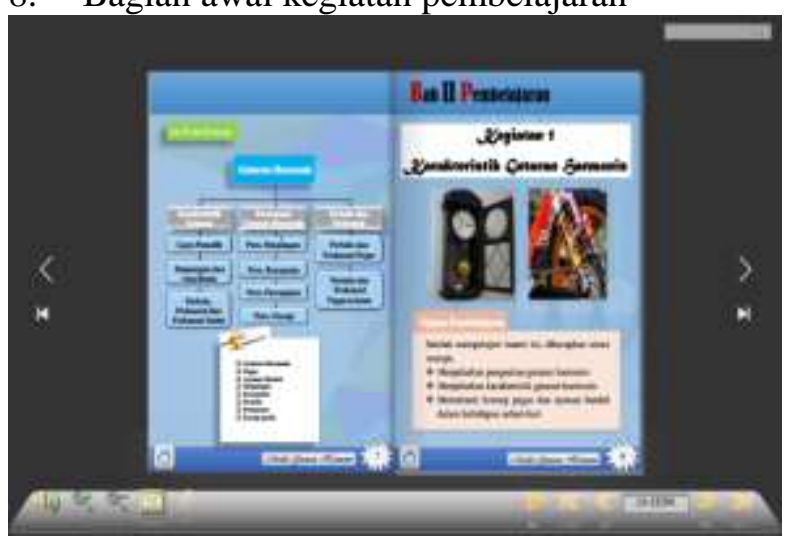

9. Tampilan materi pembelajaran

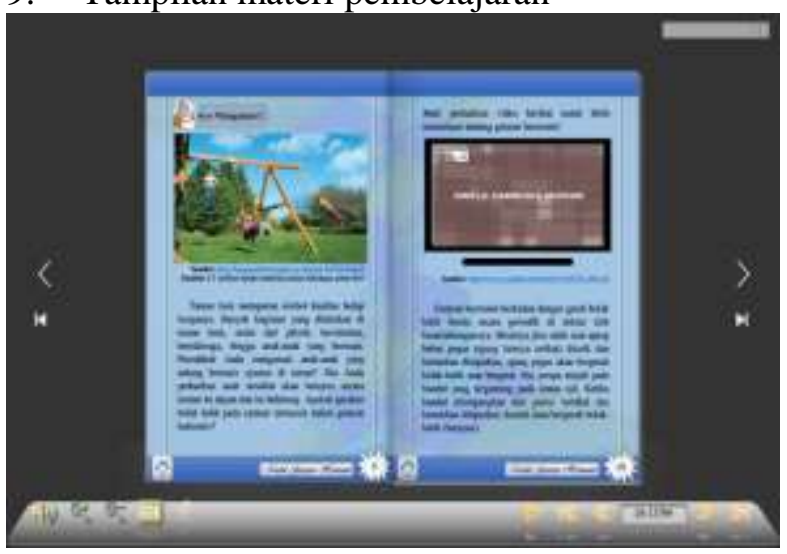

10. Tampilan uji kompetensi

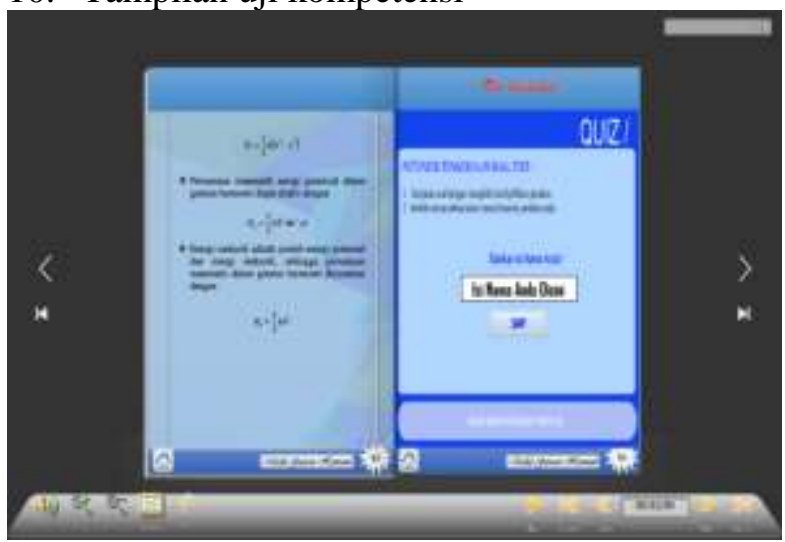

\section{Simpulan dan Saran}

Simpulan

Berdasarkan hasil pengembangan dan uji coba modul elektronik maka dihasilkan modul elektronik fisika berbasis pendekatan saintifik pada materi getaran harmonis SMA/MA menggunakan kvisoft flipbook maker yang valid dan layak digunakan.dengan skor ahli materi sebesar 30 dan ahli media sebesar 63 yang termasuk dalam kategori setuju. Produk yang dihasilkan memiliki spesifikasi antara lain software menggunakan kvisoft flipbook maker, format akhir program swf, kerangka modul elektronik terdiri dari cover modul, peta kedudukan modul, kegiatan pembelajaran per sub bab dengan contoh soal dan latihan soal serta uji kompetensi, kegiatan pembelajaran modul disusun dengan pendekatan saintifik, materi disajikan dengan persamaan yang jelas, terdapat gambar, grafik, video, animasi, simulasi. Adapun keunggulan yang terdapat pada modul elektronik yaitu modul ditampilkan dengan kegiatan pembelajaran disusun agar siswa dapat mengkonstruksi konsep, hukum atau prinsip melalui tahapan pembelajaran. Kelemahan pada modul elektronik yaitu hanya terdapat satu simulasi dikegiatan pembelajaran satu, tidak ada video dan animasi dikegiatan pembelajaran tiga, belum bisa terkoneksi dengan internet dan belum bisa digunakan pada smartphone. Hasil persepsi siswa terhadap modul elektronik yaitu 78,17 dan dikategorikan sangat setuju.

Saran

Saran yang dapat diberikan oleh peneliti bagi peneliti berikutnya adalah:

1. Pengembangan media ini disarankan untuk menguji pengaruh penggunaannya terhadap hasil belajar siswa.

2. Produk berupa modul elektronik fisika berbasis pendekatan saintifik pada materi getaran harmonis SMA/MA menggunakan kvisoft flipbook maker ini diharapkan dapat diuji coba di lapangan untuk mengetahui kefektifan produk dalam pembelajaran fisika.

3. Diharapkan agar peneliti mampu mengembangkan animasi dan simulasi yang lebih interaktif untuk percobaanpercobaan pada materi getaran harmonis.

4. Diharapkan menambahkan simulasi pada kegiatan 1 dan 2 serta menambahkan kegiatan saintifik untuk setiap sub materi.

\section{Daftar Pustaka}

Arikunto, Suharsimi. 2013. Dasar-Dasar Evaluasi Pendidikan. Jakarta: Bumi Aksara. 
Branch, Robert Maribe. 2009. Instructional Design: The ADDIE Approach. USA: Department of Educational Psychology and Instructional Technology University of Georgia

Daryanto, 2013. Menyusun Modul Bahan Ajar untuk Persiapan Guru dalam Mengajar. Yogyakarta: Gava Media.

Daryanto, 2014. Pendekatan Pembelajaran Saintifik kurikulum 2013. Yogyakarta: Gava Media.

Direktorat Pembinaan SMA. 2010. JUKNIS PENYUSUNAN PERANGAT PENILAIAN AFEKTIF DI SMA. Jakarta: Kementerian Pendidikan Nasional

Hayati, Sri dkk. 2015. Pengembangan Media Pembelajaran Flipbook Fisika untuk meningkatkan Hasil Belajar Peserta Didik. Prosiding Seminar Nasional Fisika (E-Journal) SNF2015, Volume IV

Prasetiyowati, Yeni. 2015. Pengembangan Modul Elektronik pada Mata Pelajaran Animasi 3Dimensi Materi PokokPemodelan Objek 3DKelas XI Multimedia untuk Meningkatkan Hasil Belajar di SMK Negeri 1 Magetan. Jurnal pembelajaran fisika.

Purnamawati, dkk. 2015. Penerapan E-Modul Berbasis Problem Based Learning untuk Meningkatkan Keterampilan Proses Sains dan Mengurangi Miskonsepsi Peserta Didik Kelas XI MIA 2 SMA Batik 1 Surakarta. Seminar Nasional XII, V.

Rijal, B.S. 2014. Pengembangan Modul Elektronik Perakitan dan Instalisasi Komputer Sebagai Sumber Belajar untuk Kelas X SMK PIRI I Yogyakarta, Skripsi, Universitas Negeri Yogyakarta, Yogyakarta.

Salsabila, R.P. 2013. Pengembangan Modul Elektronik Fisika sebagai Media Intruksional Pokok Bahasan Hukum Newton pada Pembelajaran Fisika di
SMA. Jurnal Pembelajaran Fisika, 1(1): 12-19.

Saripudin, Aip. 2012. Advanced Learning Physics 2A. Jakarta: Facil

Satriawati, Helna. 2015. Pengembangan EModul Interaktif sebagai Sumber Belajar Elektronika Dasar Kelas X SMKN 3 Yogyakarta. Skripsi, Universitas Yogyakarta

Susanti, Fitri, 2015,Pengembangan e-modul dengan aplikasi kvisoft flipbook maker pada pokok bahasan fluida statis untuk peserta didik sma/ma kelas $\mathrm{x}$, Skripsi, Universitas Islam Negeri Sunan Kalijaga.

Suryani, Yani, 2016, Pengembangan modul pembelajaran menggunakan learning content development system (lcds) pada materi gerak harmonik sederhana, Skripsi, Universitas Lampung.

Widoyoko, S. E. P. 2016. Teknik Penyusunan Instrumen Penelitian. Yogyakarta: Pustaka Belajar 